\title{
HUMAN RIGHTS AND AMERICAN FOREIGN POLICY
}

\author{
by Johann Spies*
}

Introduction

American involvement in the international arena vacillates and shifts at a fast pace. Since the terrorist attacks on US soil in 2001, the Bush administration has aggressively returned the US to internationalism. The American interaction on the international stage has always been unique. Currently, as the only true superpower in the international system, the effect of US foreign policy on the global human rights regime is likely to be greater than at any other time in their history.

The significant question, then, is to the position, if at all, of human rights concerns within US foreign policy. Ruggie states that international regimes which are closer to a superpower's core security interests will necessarily be stronger than those further away. ${ }^{1}$ One may then suppose that regimes which are dominant in the foreign policy of a superpower will be stronger than those less dominant.

This article analyses the position of human rights within the current administration in the US in order to determine if US foreign policy concerns itself at all with these issues when making policy decisions.

\section{$2 \quad$ Unilateralism in the Bush administration}

The Bush administration is characterised by a unilateral foreign policy, discarding the multilateral approach which predominates the foreign policy of other great powers. Continuing the firm tradition of US policy, national interests have triumphed over any incentives to seek these multilateral solutions. The Kyoto Protocol serves as an example of this phenomenon.

As one of his first acts as President, Bush withdrew executive approval from the Kyoto Protocol. A determining factor in this decision was that joining the Protocol was likely to raise energy prices due to a greater demand for natural gas, which conflicted with the Byrd-Hagel Resolution's requirement that such a treaty did not 'result in serious harm to the economy of the United States'.

* $\quad$ Final year LLB candidate, University of Pretoria.

1 JG Ruggie 'Human rights and the future international community' 112 (1983) Daedalus 93 at 104.

2 GW Bush 'Text of a letter from the President to Senators Hagel, Helms, Craig and Roberts' (13 March 2001). 
In 2002, however, Bush announced an alternative strategy according to which he committed to the reduction of greenhouse gases, including carbon dioxide, totalling $18 \%$ per unit of GDP. This plan was criticised for falling far short of the planned reductions offered by the Kyoto Protocol, however it poses a paradox with regards to actual policy. ${ }^{3}$ Instead of returning to the negotiation table for the Kyoto Protocol in order to whittle away at the treaty, the Bush administration preferred implementing a domestic plan.

This paradox in US behaviour in the international arena has often been remarked upon. It is frequently attributed to the particular rights culture which is predominant in the US. A combination of factors has led to this stance and thereby contrasts the US tendencies with that of Western Europe. Historically, the US has placed a great emphasis on domestic human rights enforcement, on the one hand, yet emphasised sovereignty in the international stage on the other. This American 'exceptionalism' is characterised by a strong human rights culture in the US but a refusal on the part of the US to make significant commitments to human rights treaties or acknowledge international court systems. Whether academics attribute these unilateral tendencies to the particular socio-polity of the American people, the political culture of isolationism or the 'pluralist' analysis of US social interests and institutions, ${ }^{4}$ there is general consensus that a failure of the US to act multilaterally does not in itself suggest that human rights is not a distinct factor in its formulation of foreign policy.

\section{Bush's foreign aid policy: The Millennium Challenge} Account

Foreign aid spending has long been a powerful tool in the US arsenal. It is also itself a useful tool in determining the factors which most strongly influence policy. Domestically, changes in foreign aid allocation are easier to effect than trade or military sanctions as they have less of an impact on the economic conditions within the US and the allocation itself, rather than the initial funding, is often within the executive function and not that of the legislative. As a result of this greater ease, foreign aid is more likely to be sensitive to individual policy considerations and would reflect human rights as sole considerations should it be present.

The Bush administration has been unexpectedly rather generous in calling for large foreign aid increases, considering that it is both a Republican administration and that their rhetoric suggested 
otherwise. In 2002, Bush called for an increase of $50 \%$ to foreign aid spending through the Millennium Challenge Account (MCA). This aid would be allocated to countries on the basis of good governance, including that they should not contrive human rights standards. Surprisingly, the targeted countries were not failed states likely to harbour terrorists which would suggest a much closer link to national security issues. 5

In theory this meant that the aid provided by the Millennium Challenge Account would be retracted where a state failed to observe such good governance, regardless of other national interests which were at play. Since 2006, 16 criteria have been put in place in order to qualify for this funding and include economic indicators on the one hand and civil, political and socio-economic rights adherence on the other. ${ }^{6}$ While the funding did not quite reach its originally expected level, $\$ 650$ million has been made available in 2004 and a further $\$ 1,5$ billion in $2005 .^{7}$

The criteria by which states are deemed eligible fall within three broad categories, namely, 'Ruling justly', 'Investing in people' and 'Economic freedom'. These are again divided into different indicators which total 16 individual criteria. The individual criteria are each tested against reports released by independent organisations, including Freedom House, the World Bank Institute, the World Health Organisation, UNESCO and others. ${ }^{8}$ The importance of such a structure is the independence of the results on which criteria eligibility are decided, which has the possible effect of preventing issues which are not defined as criteria from influencing decisions on eligibility.

Yemen is one of the states which have qualified in terms of the MCA criteria. It failed to qualify for full compliance but became eligible in terms of the threshold assistance program in 2004. Countries eligible in this manner are not able to access the larger compact grants, but are eligible for aid whilst they continue to progress towards full compliance on the 16 criteria. Towards the end of 2005, Yemen was removed from eligibility due to it having 'experienced slippages' in nine indicators, so that by 2006 it had failed on almost every single indicator." 9

Yemen was returned to eligibility in early 2007. The state undertook a significant reform initiative which included comprehensive restructuring of the judiciary through the retiring,

5 S Radelet 'Bush and foreign aid' (2003) September Foreign Affairs 104.

MCC: Indicators http://www.mcc.gov/selection/indicators/index.php (accessed 3 April 2007).

J Blum et al 'Nuts and bolts of Bill' The Washington Post (7 December 2006) A23. MCC: Indicators (n 6 above).

'MCC willing to say no (or at least, no more)' http://blogs.cgdev.org/mcamonitor/archives/2005/11/mcc_willing_to.php (accessed 14 June 2007). 
sanctioning and suspension of 30 judges, removing the President from the Supreme Judicial Council, and further economic reform and commitments as well as a re-evaluation of press laws which would have curtailed the freedom of the press further. ${ }^{10}$

Yemen illustrates two points in regards to the US foreign policy in respect of foreign aid. Firstly, it demonstrates the potential for significant success in achieving human rights practice reforms in states. For our purposes, however, it demonstrates that the Bush administration's expansion of foreign aid into the MCA has allowed for aid to be removed from a state for failure to abide by human rights standards unaffected by other considerations.

This was further reflected by the removal of eligibility of The Gambia which had achieved full compact eligibility for the fiscal year 2006. ${ }^{11}$ Approximately a year after having been acknowledged as eligible, their eligibility was suspended by the Millennium Challenge Corporation (MCC) for 'slippage by the government of The Gambia that is inconsistent with the MCA selection criteria'. ${ }^{12}$ The MCC based this decision on 'evidence of growing human rights abuses, increased restrictions on political rights, civil liberties and press freedom, as well as deteriorating economic policies and anti-corruption efforts' ${ }^{13}$

The Millennium Challenge Account is a clear indication that the Bush administration is following a global trend in having foreign aid inextricably linked with 'human development concerns'. ${ }^{14}$ The structure and functioning of the Millennium Challenge Account are such that it has made it possible to effect policies sensitive to human rights practices in states in order to determine whether foreign aid should be granted. While this is a much sought after progression in foreign policy as it concerns foreign aid distribution it is currently still limited, both in terms of the states which are affected by the fund and the percentage which the MCA funds form of the total foreign aid distributed by the US.

\section{Bush's realism}

In 2004 and 2005, the Middle East and North Africa region was the biggest beneficiary of US aid and received more than twice the aid of its closest rival, the sub-Saharan Africa region. The ten top recipients

10 'Yemen's eligibility for assistance reinstated by Millennium Challenge Corporation Board' http://yemen.usembassy.gov/yemen/MCC_feb_07.html (accessed 6 April 2007).

11 Millennium Challenge Corporation 'Report on the selection of eligible countries for fiscal year 2006' (28 July 2005) 1.

12 Millennium Challenge Corporation 'MCC notification to The Gambia' (16 June 2006) 1.

13 n 9 above.

14 O Stokke Foreign aid towards the year 2000 (1996) 86. 
of aid in that period were dominated by states which have direct national security considerations for the US, including Iraq, Afghanistan and Egypt, which were the three largest recipients, and Pakistan, the Palestinian Administered Areas and Ethiopia which were 10,9 and 5 on the list respectively. ${ }^{15}$

Further, the MCA forms part of a larger foreign policy which is not reflective of human rights concerns. The National Security Strategy of the United States ${ }^{16}$ outlined the Bush administration's commitment to a Reaganite assertion of US dominance in the international arena. This document makes it clear that the US has no intention of abandoning a unilateral approach to foreign policy, stating that ' $[\mathrm{t}]$ he US national security strategy will be based on a distinctly American internationalism that reflects the union of [their] values and [their] national interests' 17 and '[w] hile the United States will constantly strive to enlist the support of the international community, [it] will not hesitate to act alone'. ${ }^{18}$

Prior to the 11 September 2001 attacks on the US, Bush had declared himself a 'realist' in terms of international politics ${ }^{19}$ and a significant part of his administration was, and continues to be, dominated by individuals who either aligned themselves with a realist philosophy or were already so established. ${ }^{20}$ While the administration's decision to pursue military intervention in Iraq came under heavy criticism by realist academics, ${ }^{21}$ the criticism was aimed mainly towards the aspect of 'pragmatism' in that it was felt such an act would endanger the relationship between the US and its allies.

An important aspect of the realist approach to international politics has been the notion of 'egoism'. ${ }^{22}$ Morgenthau, a classical realist, stated that '[r]ealism maintains that universal moral principles cannot be applied to the actions of states' ${ }^{23}$ Donnelly reiterates this as '[e]thical considerations must give way to 'reasons of state' ${ }^{24}$ or national interest.

This aspect of realism has been apparent in the Bush administration's foreign policy. Economic and military sanctions have been used unilaterally only in cases where national security, or some

Statistics used were sourced from the Organisation for Economic Co-operation and Development http://www.oecd.org/dac/ (accessed 2 June 2007).

GW Bush 'The national security strategy of the United States' (September 2002).

Bush (n 16 above) 1.

Bush (n 16 above) 6.

Speech by Governor Bush 'A distinctly American internationalism' http:// www.mtholyoke.edu/acad/intrel/bush/wspeech.htm (accessed 6 April 2007).

M Boyle 'Utopianism and the Bush foreign policy' (2004) April Cambridge Review of International Affairs 84.

Boyle (n 20 above) 85.

RG Gilpin 'The richness of the tradition of political realism' in RO Keohane (ed) Neo-realism and its critics (1986) 305.

H Morgenthau Politics among nations: The struggle for power and peace (1973) 9. S Burchill et al Theories of international relations (2005) 31. 
other conceived national interest, has been threatened. The administration's realist approach to the 'War on Terror' has reignited the distinction drawn between 'authoritarian' and 'totalitarian' states to which the Reagan administration so firmly held. ${ }^{25}$

The result of such a distinction on foreign policy is that where national interests dictate, the call for democratisation or human rights reforms becomes tepid at best. While Pakistan was 'coldshouldered' by the US when Musharraf had first taken power, the relationship between the two states flowered after the 'War on Terror'. Musharraf's rule of Pakistan, rather than becoming more democratic, has centred around a consolidation of the authoritarianism he enjoys. Regardless of this, the US has 'waived various economic sanctions, assembled a handsome aid package that exceeded $\$ 600$ million in 2002, and restarted US-Pakistan military cooperation'.26

\section{Conclusion}

The paradox between the Millennium Challenge Account initiative and the greater part of the Bush administration's foreign policy is consistent with Carother's appraisal of Bush and his foreign policy team as having a 'split-personality'. ${ }^{27}$ The MCA's structure has made it independent of national interest concerns and creates the opportunity for foreign aid spending which is dominated by human rights concerns. On the other hand, the majority of foreign aid dispensed by the US under the Bush administration is still done in the name of national security and national interest. Further, the Bush administration's use of other foreign policy tools has not been a departure from the historic methods employed by the US.

The MCA itself has so far proved successful in effecting policy and practice change in states. Those who hope for foreign aid to become a meaningful tool in democratisation and altering state practices should not expect very much from the initiative, however. The limited scope of applicability of the MCA, as well as the unique structure it enjoys within the foreign aid dispensation of the US, makes it unlikely that it will herald massive changes in the future of US aid disbursement.

One can conclude that the vast majority of US foreign policy decisions under the Bush administration fail to take into account the human rights practices of the state with which they are dealing. While

D Carleton \& M Stohl 'The foreign policy of human rights: Rhetoric and reality from Jimmy Carter to Ronald Reagan' (1985) 7 Human Rights Quarterly 205 at 208-209.

26 T Carothers 'Promoting democracy and fighting terror' (2003) January Foreign Affairs 84

27 Burchell (n 24 above) 1. 
this is an unsurprising conclusion, there is a measure of hope that the proliferation of non-governmental organisations, such as those involved with the MCC, and greater participation by civil society might effect change in US foreign policy eventually. 